\title{
Isolation and Characterization of a Glutathione-overproducing, Captan-resistant Mutant of Azospirillum brasilense
}

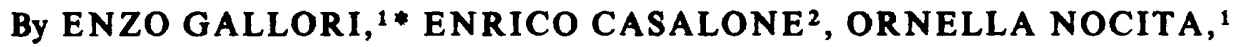 \\ LUCA TURBANTI ${ }^{1}$ AND MARIO POLSINELLI ${ }^{1}$ \\ ${ }^{1}$ Dipartimento di Biologia Animale e Genetica, University of Florence, via Romana, 17-50125 \\ Florence, Italy \\ ${ }^{2}$ Istituto Scienze Biochimiche, University of Chieti, 66100 Chieti, Italy
}

(Received 29 February 1988; revised 4 August 1988)

The fungicide Captan inhibited the growth of Azospirillum brasilense at a concentration of $25 \mu \mathrm{g} \mathrm{m}^{-1}$. When cysteine and glutathione were added to the medium they removed the toxicity of the fungicide. A spontaneous mutant was isolated which was able to grow and fix nitrogen in the presence of $100 \mu \mathrm{g}$ Captan $\mathrm{ml}^{-1}$. Characterization of the mutant indicated very high levels of glutathione and glutathione transferase activity as compared to the parent strain. The role of these cellular components in the mechanism of resistance to Captan is discussed; the involvement of a selenium-independent glutathione peroxidase appears essential to Captan resistance in the mutant strain.

\section{INTRODUCTION}

The wide use of fungicides in modern agriculture has necessitated the study of the effects of these chemicals on soil micro-organisms, including nitrogen-fixing bacteria (Anderson, 1978; Simon-Sylvestre \& Fournier, 1979). Captan or Captan-containing fungicides are toxic to Rhizobium sp. and to symbiotic $\mathbf{N}_{\mathbf{2}}$-fixation and related processes (Curley \& Burton, 1975; Graham et al., 1980; Rennie \& Dubetz, 1984; Rennie et al., 1985; Banerjee \& Banerjee, 1987). Mutants resistant to various fungicides have been isolated from different species of Rhizobium (Odeyemi \& Alexander, 1977; Ruiz-Sainz et al., 1984; Rennie, 1986).

Conflicting results are available on the effects of pesticides on growth and nitrogenase activity of Azospirillum, a bacterium able to fix nitrogen in association with the roots of important cereals and whose agronomic use has been suggested (Döbereiner \& Day, 1975; Okon, 1985a, b). Alvarez \& Sleiman (1983) reported that three insecticides and ten herbicides had no effect on the growth and nitrogenase activity of different strains of Azospirillum lipoferum and Azospirillum brasilense, but Gadkari (1988) found that the herbicides Metribuzin and Ethiozin caused a marked decrease in nitrogenase activity.

Little information is available on the mechanism of action and the fate of Captan in bacterial cells (Agnihotri, 1971). Studies, mainly done on fungal and animal cells, suggest a possible involvement of cysteine, glutathione and other thiol compounds in antagonizing the action of Captan (Rup Lal \& Saxena, 1980; Sisler, 1982; Somerville, 1986). In view of the possible utilization of Azospirillum sp. as a biofertilizer for cereal crops (Okon \& Kapulnik, 1986) it is important to investigate the effect of fungicides on this bacterium. In this paper, the effects of three structurally related substituted phthalimide fungicides (Captan, Folpet and Captafol) on the growth and nitrogenase activity of $A$. brasilense (strain $\mathrm{Cd}$ ) and the isolation and characterization of a mutant resistant to Captan are described.

Abbreviation: CHP, cumene hydroperoxide. 


\section{METHODS}

Bacterial strains. A. brasilense Cd (ATTC 29710) and SPF 410, a spontaneous mutant resistant to Captan, derived from the $\mathrm{Cd}$ strain were used.

Media. MSP medium (Bani et al., 1980) was used. Unless otherwise specified the medium was not supplied with any nitrogen source. Complete medium (CM) was MSP plus yeast extract $\left(5 \mathrm{~g}^{-1}\right)$. Growth conditions were as described by Bani et al. (1980).

Chemicals. Captan ( $N$-trichloromethylthio-4-cyclohexene-1,2-dicarboximide), Folpet ( $N$-trichloromethylthiophthalimide) and Captafol (tetrachloromethylmercaptocyclohexene-dicarboximide) were obtained from S. Ehrenstorfer, Augsburg, FRG. They were dissolved in dimethylsulphoxide (DMSO) before use.

Determination of fungicide minimal inhibitory concentration (MIC). Captan, Folpet and Captafol solutions in DMSO were mixed with MSP agar to obtain plates at increasing concentrations of fungicide (from 0 to $100 \mu \mathrm{g} \mathrm{ml}^{-1}$ ). Suspensions of bacterial cultures suitably diluted (about 100 colonies per plate) were seeded onto the plates. After $48 \mathrm{~h}$ at $34^{\circ} \mathrm{C}$ the plates were examined for growth of colonies. Agar plates containing 0.1\% (v/v) DMSO were used as controls.

Removal of fungicide toxicity by natural metabolites. All natural amino acids, purine and pyrimidine bases and reduced glutathione (GSH) were assayed for the ability to remove the $A$. brasilense growth inhibition by the fungicide. Each metabolite was added, at different concentrations, to MSP solid medium plates containing $50 \mu \mathrm{g}$ Captan ml-1, $60 \mu \mathrm{g}$ Folpet ml-1 or $100 \mu \mathrm{g}$ Captafol ml-1. A suspension of $5 \times 10^{7} \mathrm{cells} \mathrm{ml}^{-1}$ of strain Cd was streaked onto the plates and growth estimated visually after $2 \mathrm{~d}$ incubation at $34^{\circ} \mathrm{C}$.

Isolation of Captan-resistant mutants. Spontaneous Captan-resistant-mutants were obtained by plating cells from a late exponential phase culture of $A$. brasilense strain Cd on MSP medium containing $50 \mu \mathrm{g}$ Captan ml ${ }^{-1}$. After $3 \mathrm{~d}$ at $34^{\circ} \mathrm{C}$, resistant colonies were picked up and subcultured on the same selective medium to check the level of resistance to Captan.

Cell-free extract preparation. Bacterial cells (strain Cd or SPF 410) were grown overnight in $20 \mathrm{ml} \mathrm{CM}$ and then diluted in $1200 \mathrm{ml}$ of the same medium. Growth was followed up to the end of the exponential phase. The cells were harvested by centrifugation and washed twice with saline. The cell pellet was broken by grinding in a mortar with alumina (type 305, Sigma) and resuspended $1: 5(\mathrm{w} / \mathrm{v})$ in $0.1 \mathrm{M}$-phosphate buffer (pH 6.5) containing 2 mM-EDTA. Alumina and cell debris were removed by centrifuging $\left(600 \mathrm{~g}_{\mathrm{g}}, 10 \mathrm{~min}\right)$, the supernatant was collected and centrifuged at $13000 \mathrm{~g}$ for $\mathbf{4 5} \mathrm{min}$. The cell-free extract obtained was used to assay GSH, enzymic activities and protein content.

GSH determination. The determination of total glutathione, reported as the sum of reduced (GSH) and oxidized (GSSG) forms of glutathione (GSH + 2 GSSG), was done as described by Akerboom \& Sies (1981). To $800 \mu l$ supernatant were added $3.2 \mathrm{ml} 1 \mathrm{M}-\mathrm{HClO}_{4}$ containing $2 \mathrm{mM}$-EDTA and the resulting mixture was centrifuged at $10000 \mathrm{~g}$ for $15 \mathrm{~min}$. The supernatant was adjusted to about pH 7 with $0.3 \mathrm{M}-\mathrm{MOPS}$ containing $2 \mathrm{M}-\mathrm{NaOH}$. The volume changes were taken into account in the calculation of the GSH concentration.

Enzyme assays. Nitrogenase activity of whole cells was assayed by the acetylene reduction method (Postgate, 1972); the cultures for nitrogenase assay were prepared as previously described (Gallori \& Bazzicalupo, 1985). The number of viable cells in the presence of different concentrations of Captan was determined by plating cultures on $\mathrm{CM}$ medium for $48 \mathrm{~h}$.

GSH transferase (EC 2.5.1.18) was assayed using 1-chloro-2,4-dinitrobenzene (CDNB) as substrate (Habig et al., 1974). The formation of conjugated derivatives was followed spectrophotometrically at $340 \mathrm{~nm}$ as a function of time. The standard assay mixture contained 0.1 M-potassium phosphate buffer (pH 6.5), 1 mM-EDTA, 2 mM-GSH, $1 \mathrm{mM}-\mathrm{CDNB}$ and a volume of cell-free extract corresponding to $0.5-1.0 \mathrm{mg}$ protein.

GSH peroxidase activity was determined by the method described by Lawerence \& Burk (1976) using $1.2 \mathrm{mM}$ cumene hydroperoxide (CHP). In this assay, the GSSG produced by the hydroperoxide-dependent oxidation of GSH was reduced by GSH reductase with concomitant consumption of NADPH, which was followed spectrophotometrically at $340 \mathrm{~nm}$. Selenium-dependent GSH peroxidase (EC 1.11.1.9) activity was determined as above, but $\mathrm{CHP}$ was replaced by $0.25 \mathrm{mM}-\mathrm{H}_{2} \mathrm{O}_{2}$. Selenium-independent GSH peroxidase activity was computed by the difference between CHP and $\mathrm{H}_{2} \mathrm{O}_{2}$ activities (Wendel, 1980; Tappel et al., 1982).

GSH reductase (EC 1.6.4.2) activity was assayed as described by Carlberg \& Mannervik (1975), by following the oxidation of NADPH.

All three enzymic assays were done at room temperature in a Beckman model 35 spectrophotometer. Cell-free extracts, separately prepared from different cultures of Cd or SPF 410, were assayed. Each cell-free extract was assayed in duplicate both for protein (by the Lowry method) and for enzyme activities. Each assay was linear as a function of time and protein concentration.

\section{RESULTS}

Effect of substituted phthalimide fungicides on A. brasilense growth. On MSP solid medium Captan $\left(25 \mu \mathrm{g} \mathrm{ml}^{-1}\right)$ blocked the growth of strain Cd, whereas the MICs of Folpet and Captafol 
Table 1. Removal of Captan, Folpet and Captafol toxicity by cysteine or glutathione in A. brasilense strain $\mathrm{Cd}$

\begin{tabular}{|c|c|c|c|c|c|c|}
\hline \multirow[b]{3}{*}{ Fungicide } & \multicolumn{6}{|c|}{ Growth } \\
\hline & \multicolumn{3}{|c|}{$\begin{array}{l}\text { Cysteine concn } \\
\left.[\mathrm{g} \text { (g fungicide })^{-1}\right]\end{array}$} & \multicolumn{3}{|c|}{$\begin{array}{c}\text { GSH concn } \\
\left.\text { [g (g fungicide })^{-1}\right]\end{array}$} \\
\hline & 0.5 & 1 & 1.5 & 0.5 & 1 & 1.5 \\
\hline Captan $\left(50 \mu \mathrm{g} \mathrm{ml}^{-1}\right)$ & - & - & \pm & - & $\mp$ & + \\
\hline Folpet $(60 \mu \mathrm{g} \mathrm{ml}-1)$ & - & $\mp$ & $\bar{t}$ & - & \pm & + \\
\hline Captafol $\left(100 \mu \mathrm{g} \mathrm{ml}^{-1}\right)$ & - & \pm & + & - & $\bar{t}$ & + \\
\hline
\end{tabular}

Table 2. Acetylene-reduction activity and survival of A. brasilense parent strain and Captan-resistant mutant SPF 410 in the presence of various concentrations of Captan

Values are the mean $\pm S D$ of four experiments with two replicates per experiment.

$\begin{array}{cccc}\text { Strain } & \begin{array}{c}\text { Captan } \\ \text { concn } \\ \left(\mu \mathrm{g} \mathrm{m} \mathrm{m}^{-1}\right)\end{array} & \begin{array}{c}\text { Acetylene } \\ \text { reduction }\end{array} & \begin{array}{c}10^{-7} \times \text { No. } \\ \text { of cells }\end{array} \\ \text { Cd } & 0 & 1.42 \pm 0.24 & 2.2 \pm 0.2 \\ & 2.5 & 1.43 \pm 0.18 & 2.3 \pm 0.3 \\ & 5 & 1.08 \pm 0.14 & 1.8 \pm 0.2 \\ \text { SPF } 410 & 10 & 0.54 \pm 0.06 & 1.3 \pm 0.1 \\ & 25 & 0 & 0 \\ & 0 & 1.39 \pm 0.20 & 2.0 \pm 0.2 \\ & 2.5 & 1.40 \pm 0.21 & 2.1 \pm 0.2 \\ & 5 & 1.40 \pm 0.23 & 2.0 \pm 0.2 \\ & 10 & 1.38 \pm 0.19 & 2.0 \pm 0.2 \\ & 25 & 1.36 \pm 0.16 & 1.9 \pm 0.2 \\ & & & \end{array}$

were 35 and $60 \mu \mathrm{g} \mathrm{ml}^{-1}$, respectively. Growth curves in the presence of Captan in MSP liquid medium indicated that $15 \mu \mathrm{g}$ Captan $\mathrm{ml}^{-1}$ appreciably reduced the growth rate of the culture, while $30 \mu \mathrm{g} \mathrm{ml}^{-1}$ completely inhibited growth (data not shown).

Ability of natural metabolites to remove the growth inhibition by fungicides. Among the natural metabolites assayed, only cysteine and GSH were able to remove growth inhibition by Captan, Folpet and Captafol. The concentration of GSH or cysteine required for removing the inhibition was 1.5 times that of the fungicides (Table 1).

Isolation and characterization of mutants resistant to Captan. Thirteen spontaneous mutants resistant to Captan were selected by plating cells of $A$. brasilense Cd on MSP medium containing $50 \mu \mathrm{g} \mathrm{Captan} \mathrm{ml}^{-1}$. The frequency of resistant mutants was about $5 \times 10^{-7}$. One of the mutants, designated SPF 410, was able to grow on solid MSP in the presence of $100 \mu \mathrm{g}$ Captan ml-1. This mutant also appeared resistant to $125 \mu \mathrm{g}$ Folpet $\mathrm{ml}^{-1}$ and $150 \mu \mathrm{g} \mathrm{Captafol} \mathrm{m} \mathrm{m}^{-1}$.

Addition of Captan $\left(2.5-10 \mu \mathrm{g} \mathrm{ml}^{-1}\right)$ did not affect the survival or the nitrogenase activity of the mutant, while the survival of the parental strain was reduced (Table 2).

Determination of GSH content and GSH metabolizing enzyme activity in the parental and mutant strain SPF 410. The GSH concentration in the mutant SPF 410 was $1121 \pm 245.8 \mathrm{nmol}$ per g of cells compared to $11.0 \pm 3.1 \mathrm{nmol}$ per $\mathrm{g}$ of cells in the parent strain (values are the means $\pm \mathrm{SD}$ of three experiments, each with two replicates). GSH transferase activity was 10-times higher in 
Table 3. Activities of GSH-metabolizing enzymes in A. brasilense parent strain $(C d)$ and Captan-resistant mutant (SPF 410)

Values are the mean \pm SD of three experiments with two replicates per experiment.

\begin{tabular}{|c|c|c|c|c|c|}
\hline \multirow[b]{3}{*}{ Strain } & \multicolumn{5}{|c|}{ Enzyme activity } \\
\hline & & \multicolumn{3}{|c|}{ GSH peroxidase $†$} & \multirow[b]{2}{*}{$\begin{array}{c}\text { GSH } \\
\text { reductase† }\end{array}$} \\
\hline & $\begin{array}{c}\text { GSH } \\
\text { transferase* }\end{array}$ & $\begin{array}{l}\text { Total } \\
(a)\end{array}$ & $\begin{array}{c}\text { Selenium } \\
\text { dependent } \\
\text { (b) }\end{array}$ & $\begin{array}{c}\text { Selenium } \\
\text { independent } \\
(a-b)\end{array}$ & \\
\hline $\begin{array}{l}\text { Cd } \\
\text { SPF } 410\end{array}$ & $\begin{array}{l}0.45 \pm 0.07 \\
4.50 \pm 0.80\end{array}$ & $\begin{array}{r}11.0 \pm 2.6 \\
3.2 \pm 0.8\end{array}$ & $\frac{15 \cdot 0 \pm 9 \cdot 0}{0}$ & $\begin{array}{c}0 \\
3 \cdot 2\end{array}$ & $\begin{array}{l}108 \pm 4 \\
105 \pm 12\end{array}$ \\
\hline
\end{tabular}

the mutant than in the parent strain. (Table 3). Furthermore, the mutant completely lacked the ability to reduce $\mathrm{H}_{2} \mathrm{O}_{2}$, while the selenium-independent GSH peroxidase activity of the mutant was $3.2 \mathrm{nmol} \mathrm{min}$ m $^{-1}$ (mg protein) $)^{-1}$ whereas it was totally absent from the parent strain. GSH reductase activities of the two strains were comparable.

\section{DISCUSSION}

Captan is harmful for symbiotic nitrogen-fixing bacteria (Rennie et al., 1985). We found that $25 \mu \mathrm{g}$ Captan $\mathrm{ml}^{-1}$ irreversibly blocked the growth of $\boldsymbol{A}$. brasilense. Captan appeared to be the more toxic compound among the three substituted phthalimide fungicides assayed, in agreement with the data obtained for $R$. trifolii (Ruiz-Sainz et al., 1984). Both GSH and cysteine were capable of antagonizing the toxic effect of Captan, Folpet and Captafol. The detoxification mechanism was probably the same for the three fungicides assayed. The content of GSH found in $A$. brasilense was lower than that reported by Fahey et al. (1978) for other Gram-negative bacteria.

The availability of Captan-resistant mutants, besides making compatible the combined use of fungicide and soil or seed-applied bacterial inoculation (Rennie, 1986), offers the possibility of investigating the mechanism of resistance to the fungicide. One of the mutants isolated, SPF 410, was able to grow and fix nitrogen in the presence of high levels of Captan $\left(100 \mu \mathrm{g} \mathrm{ml}^{-1}\right)$ and showed cross-resistance towards Folpet and Captafol. The involvement of GSH in the detoxification process was supported by the high intracellular concentration of GSH found in SPF 410. Compared to the parent strain, the mutant SPF 410 showed a notably higher GSH transferase activity and had a selenium-independent GSH peroxidase activity (Table 3). As found by Lawerence et al. (1978) and Prohaska (1980) the selenium-independent GSH peroxidase activity is identifiable with some form(s) of GSH transferase and therefore similar isoenzyme form(s) may be induced in our mutant. However, our data do not exclude that the 10fold increase in the GSH transferase activity might be due to a 10-fold increase in enzyme concentration. The role of GSH transferase in catalysing the reaction of GSH with Captan, leading to less toxic metabolites, has been discussed by Somerville (1986).

Surprisingly, it was also found that the mutant completely lacked the selenium-dependent GSH peroxidase activity. Thus the total peroxide reducing power of the cell, estimated by using CHP as a substrate, was considerably reduced in spite of the contribution made by the seleniumindependent GSH peroxidase activity. In contrast, the GSH reductase activity of the mutant was the same as that of the parent strain; consequently, the capacity of the cell to regenerate GSH from the GSSG produced by the GSH peroxidase reaction was unchanged. 
In conclusion, the high levels of GSH found in the mutant suggest an involvement of this thiol in the detoxification process, and the rise in the GSH transferase activity in the mutant is probably part of the mechanism conferring resistance to Captan. We cannot explain the decrease in GSH peroxidase activity and the role of this enzyme in the resistance to Captan. Further investigation is needed to elucidate the function of these cellular components in the mechanism of Captan resistance.

\section{REFERENCES}

AGNIHOTRI, V. P. (1971). Persistance of captan and its effect on microflora, respiration and nitrification of forest nursery soil. Canadian Journal of Microbiology 17, 377-383.

ARerboom, T. P. M. \& Sies, H. (1981). Assay of glutathione, glutathione disulfide, and glutathione mixed disulfides in biological samples. Methods in Enzymology 77, 373-382.

Alvarez, R. \& Slemin, L. A. (1983). Effects of some pesticides on Azospirillum lipoferum and Azospirillum brasilense in pure culture. Revista Facultad de Agronomia 4, 277-281.

ANDERSON, J. R. (1978). Pesticide effects on non-target soil microorganisms. In Pesticide Microbiology, pp. 313-533. Edited by I. R. Hill and S. J. L. Wright. London: Academic Press.

BANERJEe, A. \& BANERJEE, A. K. (1987). Influence of captan on some microorganisms and microbial processes related to the nitrogen cycle. Plant and Soil 102, 239-245.

Bani, D., Barberio, C., Bazzicalupo, M., Favilli, F., GALlORI, E. \& Polsinelli, M. (1980). Isolation and characterization of glutamate synthase mutants of Azospirillum brasilense. Journal of General Microbiology 119, 239-244.

Carlberg, I. \& Mannervix, B. (1975). Purification and characterization of the flavoenzyme glutathione reductase from rat liver. Journal of Biological Chemistry 250, 5475-5480.

CURLeY, R. L. \& Burton, J. C. (1975). Compatibility of Rhizobium japonicum with chemical seed protectants. Agronomy Journal 67, 807-808.

DÖbereiner, J. \& DAY, J. M. (1975). Associative symbiosis in tropical grasses: characterization of microorganisms and dinitrogen fixing sites. In Proceedings of the Ist International Symposium on Nitrogen Fixation, pp. 518-538. Edited by W. E. Newton and J. C. Nyman. Pullman: Washington State University Press.

Fahey, R. C., Brown, W. C., Adams, W. B. \& WorshaM, M. B. (1978). Occurrence of glutathione in bacteria. Journal of Bacteriology 133, 1126-1129.

GADKARI, D. (1988). Influence of herbicides on growth and nitrogenase activity of Azospirillum. In Azospirillum. IV. Genetics, Physiology, Ecology, pp. 150-158. Edited by W. Klingmuller. Berlin: Springer.

Gallori, E. \& Bazzicalupo, M. (1985). Effect of nitrogen compounds on nitrogenase activity in Azospirillum brasilense. FEMS Microbiology Letters 28, 35-38.

Graham, P. H., Ocampo, G., Ruiz, L. D. \& DuQue, A. (1980). Survival of Rhizobium phaseoli in contact with chemical seed protectants. Agronomy Journal 72, 625-627.

Habig, V. H., PABst, M. J. \& Jakoby, W. B. (1974). Glutathione S-transferases, the first enzymatic step in mercapturic acid formation. Joumal of Biological Chemistry 249, 7130-7139.

LAWERENCE, R. A. \& BURK, R. F. (1976). Glutathione peroxidase activity in selenium deficient rat liver. Biochemical and Biophysical Research Communications 71, 952-958.

lawerence, R. A., Parkhill, L. K. \& Burk, R. F. (1978). Hepatic cytosolic non selenium-dependent glutathione peroxidase activity: its nature and the effect of the selenium deficiency. Journal of Nutrition 108, 981-987.

ODEYEMI, O. \& AlEXANDER, M. (1977). Resistance of Rhizobium strains to phygon, spergon and thiuram. Applied and Environmental Microbiology 133, 784790.

OroN, Y. (1985a). The physiology of Azospirillum in relation to its utilization as inoculum for promoting growth of plants. In $\mathrm{N}_{2}$-fixation and $\mathrm{CO}_{2}$ Metabolism, pp. 165-174. Edited by P. W. Ludden \& S. B. Burns. New York: Elsevier.

OKon, Y. (1985b). Azospirillum as a potential inoculant for agriculture. Trends in Biotechnology 3, 223228.

OKON, Y. \& KAPULNIK, Y. (1986). Development and function of Azospirillum inoculated roots. Plant and Soil 90, 3-16.

PostGate, J. R. (1972). The acetylene reduction test for nitrogen fixation. Methods in Microbiology 6B, 343365.

Prohaska, J. R. (1980). The glutathione peroxidase activity of glutathione S-transferase. Biochimica et biophysica acta 611, 87-98.

RENNIE, R. J. (1986). Selection for captan tolerance in the Rhizobium phaseoli-Phaseolus vulgaris $\mathrm{L} . \mathrm{N}_{2}$ fixing symbiosis. Canadian Journal of Soil Science 66, 143-150.

RENNIE, R. J. \& DUBETZ, S. (1984). Effect of fungicide and herbicide on nodulation and $N_{2}$ fixation in soybean fields lacking indigenous Rhizobium japonicum. Agronomy Journal 76, 451-454.

Rennie, R. J., Howard, R. J., Swanson, T. A. \& FLORES, G. H. A. (1985). The effect of seed-applied pesticides on growth and $\mathbf{N}_{2}$ fixation in pea, lentil and fababean. Canadian Journal of Plant Science 65, 23-28.

Ruiz-Sainz, J. E., Beringer, J. E. \& GutierrezNAVARRO, A. M. (1984). Effect of the fungicide captafol on the survival and symbiotic properties of Rhizobium trifolii. Journal of Applied Bacteriology 57 , 361-367.

RuP Lal \& SAXENA, D. M. (1980). Cytological and biochemical effects of pesticides on microorganisms. Residue Review 73, 49-86.

Simon-SYLVESTRe, G. \& FOURNIER, J. C. (1979). Effects of pesticides on the soil microflora. Advances in Agronomy 31, 1-92. 
StsLER, H. D. (1982). Biodegradation of agricultural fungicides. In Biodegradation of Pesticides, pp. 133155. Edited by F. Matsamura and C. R. Krishna Marti. New York: Plenum Press.

SOMBR VILL, L. (1986). The metabolism of fungicides. Xenobiotica 16, 1017-1030.

TAPPEL, M. E., ChaUdier, J. \& TAPPEL, A. L. (1982).
Glutathione peroxidase activities of animal tissues. Comparative Biochemistry and Physiology 73B, 945949.

WenDel, A. (1980). Glutathione peroxidase. In Enzymatic Basis of Detoxification, vol. 1, pp. 333-348. Edited by W. B. Jakoby. New York: Academic Press. 